\begin{tabular}{l} 
DURNAI, RIS'IT \\
(Rekayasa Sistem dan Teknologi Informasi) \\
Vol.1 No.2 (2017) $146-152 \mid$ ISSN Media Elektronik : 2580-0760 \\
\hline
\end{tabular}

\title{
Evaluasi SDM Sistem Informasi Akademik Poltekkes Kemenkes Padang Menggunakan Framework COBIT 5
}

\author{
Alsri Windra Doni \\ Jurusan Kebidanan, Prodi Diploma IV, Poltekkes Kemenkes Padang, alsriwindradoni79@ gmail.com
}

\begin{abstract}
The purpose of this research is to know the level of capability and recommendation recommendation of improvement of academic information system of Polytechnic of Health Ministry of Padang especially human resource management (process APO07) by using COBIT framework 5. This research is qualitative descriptive research using COBIT framework 5. This research procedure begins by conducting observations, interviews, literature review, providing questionnaires to the parties involved in the management of academic information systems. The result showed that the level of capability for academic information system of Polytechnic of Health Ministry of Padang for APO domain in APO07 process failed to reach level 1 with category of Partially Achieved (49,67\%). The results of this data processing become the basis of recommendations for improving the management of academic information system Poltkekkes Kemenkes Padang to reach the target level 3.
\end{abstract}

Keywords: Academic Information Systems; COBIT 5; Level Capability

\begin{abstract}
Abstrak
Tujuan penelitian ini adalah untuk mengetahui tingkat kapabilitas dan usulan rekomendasi perbaikan sistem informasi akademik Politeknik Kesehatan Kemenkes Padang khususnya pengelolaan sumber daya manusia (proses APO07) dengan menggunakan framework COBIT 5. Penelitian ini merupakan penelitian deskriptif kualitatif menggunakan kerangka kerja COBIT 5. Prosedur penelitian ini dimulai dengan melakukan obervasi, wawancara, kajian pustaka, memberikan kuesioner kepada pihak-pihak yang terlibat dalam pengelolaan sistem informasi akademik. Hasil penelitian diketahui bahwa tingkat kapabilitas untuk sistem informasi akademik Politeknik Kesehatan Kemenkes Padang untuk domain APO pada proses APO07 gagal mencapai level 1 dengan kategori Partially Achieved (49,67\%). Hasil pengolahan data ini menjadi dasar rekomendasi untuk perbaikan pengelolaan sistem informasi akademik Poltkekkes Kemenkes Padang untuk mencapai target level 3 .
\end{abstract}

Kata Kunci : Sistem Informasi Akademik; COBIT 5; Tingkat Kapabilitas

(C) 2017Jurnal RESTI

\section{Pendahuluan}

Politeknik Kesehatan Kemenkes Padang merupakan sekolah pendidikan tenaga Kesehatan,yang berada dibawah Kementerian Kesehatan RI. Tugas pokoknya melaksanakan pembangunan pendidikan Kesehatan kepada peserta didik sesuai dengan visi dan misi serta tujuan Poltekkes Kemenkes Padang.Jumlah mahasiswa saat ini \pm 2.150 orang, tentu membutuhkan sumber daya manusia yang handal dalam melayani mahasiswa khususnya pelayanan sistem informasi akademik.

Politeknik Kesehatan Kemenkes Padang dalam melayani mahasiswa berusaha memberikan pelayanan terbaik untuk mahasiswa. Hal ini dibuktikan dengan memanfaatkan teknologi informasi untuk sistem informasi akademik di Politeknik Kesehatan Kemenkes Padang dengan menyediakan layanan sistem informasi akademik bagi dosen dan mahasiswa khususnya dalam informasi nilai semester dan dan kartu rencana studi.

Pemanfaatan TI dalam lembaga pendidikan tinggi khususnya pada sistem informasi akademik Politeknik Kesehatan Kemenkes Padang dalam pelayanan manajemen pendidikan tinggi sudah tentu bisa dikatakan sangat tepat. Penggunaan TI dalam mendukung layanan sistem informasi akademik memunculkan resiko tingginya biaya investasi, baik dari segi pengadaan perangkat keras, pengembangan 
perangkat lunak, implementasi serta pemeliharaan sistem.

Sistem informasi Akademik Politeknik Kesehatan Kemenkes Padang dibangun dengan tujuan agar pelaksanaan proses akademik dapat berjalan sesuai dengan yang diharapkan. Sistem informasi Akademik ini dikelola oleh Kepala Bagian Akademik Politeknik Kesehatan Kemenkes Padang yang bekerjasama dengan Unit Pelaksana Teknis (UPT) Komputer, Dalam hal pengolahan data akademik mahasiswa.

Sejauh ini penerapan sistem informasi akademik sangat membantu proses akademik di tingkat direktorat, jurusan, program studi, dosen maupun mahasiswa. Sementara itu penerapan sistem informasi akademik di Politeknik Kesehatan Kemenkes Padang masih memiliki permasalahan yang mengganggu pengguna.

Permasalahan yang sering muncul adalah belum optimalnya pelayanan TI pada sistem informasi akademik, belum adanya jaminan layanan TI dapat di akses kapan saja, belum optimalnya pengawasan pimpinan organisasi kepada pihak pengelola sistem informasi akademik, belum maksimalnya pelayanan SDM TI dalam penanganan permasalahan TI di Politeknik Kesehatan Kemenkes Padang.

Berdasarkan uraian diatas, sangat perlu dilakukan evaluasi terhadap layanan sistem informasi akademik Politeknik Kesehatan Kemenkes Padang dengan tujuan untuk melakukan perbaikan dan peningkatan layanan sistem informasi akademik yang ada.

\section{Tinjauan Pustaka/Penelitian Sebelumnya}

Audit sistem informasi merupakan proses pengumpulan dan evaluasi fakta untuk mengetahui bagaimana tingkat kesesuaian antara aplikasi sistem informasi dengan prosedur yang telah ditetapkan dan mengetahui apakah suatu sistem telah didisain dan diimplementasikan secara efektif, efisien dan ekonomis serta telah melindungi aset, menjaga integritas data, dan memungkinkan tujuan organisasi tercapai efektif dengan memakai sumber daya secara efisien[1].

Dalam penelitian ini untuk mengevaluasi sistem informasi akademik menggunakan framework COBIT 5 karena memiliki keunggulan dibandingkan dengan framework yang lain dari segi kelengkapan dimana proses-proses TI dalam COBIT lebih komprehensif mencakup semua prinsip tata kelola TI dibandingkan dengan framework lain.

"Control Objectives for Information and related Technology (COBIT) adalah sekumpulan dokumentasi best practices untuk IT governance yang dapat membantu auditor, manajemen dan pengguna (user) untuk menjembatani gap antara resiko bisnis, kebutuhan kontrol serta permasalahan-permasalahan teknis"'[2].
COBIT (Control Objectives for Information and related Technology) merupakan seperangkat pedoman umum(best practice) untuk manajemen TI yang dibuat oleh Information sistem Audit and Control Association (ISACA), dan IT Governance Institue (ITGI) pada tahun 1996[3].

COBIT bermanfaat bagi auditor karena merupakan teknik yang dapat membantu dalam mengindetifikasi IT control issues. COBIT berguna bagi para IT users karena memperoleh keyakinan atas kehandalan systen aplikasi yang dipergunakan. Sedangkan para manager memperoleh manfaat dalam keputusan investasi di bidang IT serta infrastrukturnya, menyusun strategi IT plan, menentukan infromation architecture dan keputusan atas procerument/mesin.

Pengembangan COBIT dilakukan oleh IT Governance Institute (ITGI), yang merupakan bagian dari Information Sistems Audit and Control Association (ISACA). COBIT memberikan arahan (guidelines) yang berorientasi pada bisnis, dan karena itu business process owners dan manajer, termasuk juga auditor dan pengguna, diharapkan dapat memanfaatkan arahan ini dengan sebaik-baiknya.

Misi COBIT adalah untuk meneliti, mengembangkan, mempublikasikan dan mempromosikan otoritatif, upto-date, yang diterima secara internasional framework kontrol IT governance untuk diadopsi perusahaan dan digunakan oleh manager bisnis, professional IT dan professional asuransi[4].

\subsection{Implementasi COBIT 5}

COBIT 5 didasarkan pada lima prinsip kunci untuk tata kelola dan manajemen TI perusahaan (lihat Gambar 1). Kelima prinsip ini memungkinkan perusahaan untuk membangun sebuah kerangka tata kelola dan manajemen yang efektif, yang dapat mengoptimalkan investasi dan penggunaan TI untuk mendapatkan keuntungan bagi para stakeholder [5].

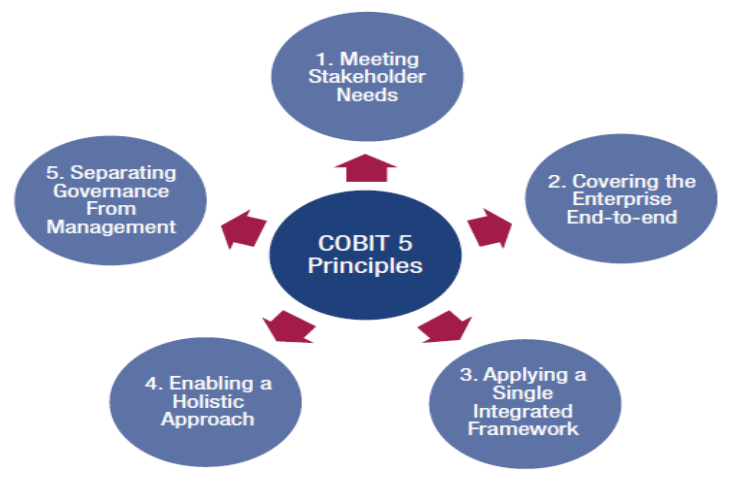

Gambar.1 Lima prinsip dalam COBIT 5 
Prinsip 1 : Meeting Stakeholder Needs (memenuhi kebutuhan stakeholder)

Berfungsi untuk pendefinisan prioritas untuk implementasi, perbaikan, dan jaminan. Kebutuhan stakeholder diterjemahkan ke dalam Goals Cascade menjadi tujuan yang lebih spesifik, dapat ditindaklajuti dan disesuaikan, dalam konteks : Tujuan perusahaan (Enterprise Goal), Tujuan yang terkait IT (IT-related Goal), Tujuan yang akan dicapai enabler (Enabler Goal).

Selain itu sistem tata kelola harus mempertimbangkan seluruh stakeholder ketika membuat keputusan mengenai penilaian manfaat, resource dan risiko.

Prinsip 2 : Covering enterprise end-to-end (melingkupi seluruh perusahaan)

Berfungsi untuk mengintegrasikan tata kelola TI perusahaan kedalam tata kelola perusahaan. Sistem tata kelola TI yang diusung COBIT 5 dapat menyatu dengan sistem tata kelola perusahaan dengan mulus.

Prinsip kedua ini juga meliputi semua fungsi dan proses yang dibutuhkan untuk mengatur dan mengelola TI perusahaan dimanapun informasi diproses.

Prinsip 3 : Applying a single intergrated framework (menerapkan kerangka tunggal yang terintegrasi)

Sebagai penyelarasan diri dengan standar dan framework relevan lain, maka perusahaan mampu menggunakan COBIT 5 sebagai framework tata kelola umum dan integrator. Selain itu prinsip ini menyatukan semua pengetahuan yang sebelumnya tersebar dalam berbagai framework ISACA (COBIT, VAL IT, Risk IT, BMIS, ITAF, dll).

Prinsip 4 : Enabling a holistic approach (menggunakan pendekatan yang menyeluruh)

COBIT 5 memandang bahwa setiap enabler saling mempengaruhi satu sama lain dan menentukan apakah penerapan COBIT 5 akan berhasil.COBIT 5 menjelaskan tujuh kategori yang berperan sebagai penggerak seperti Gambar 2.

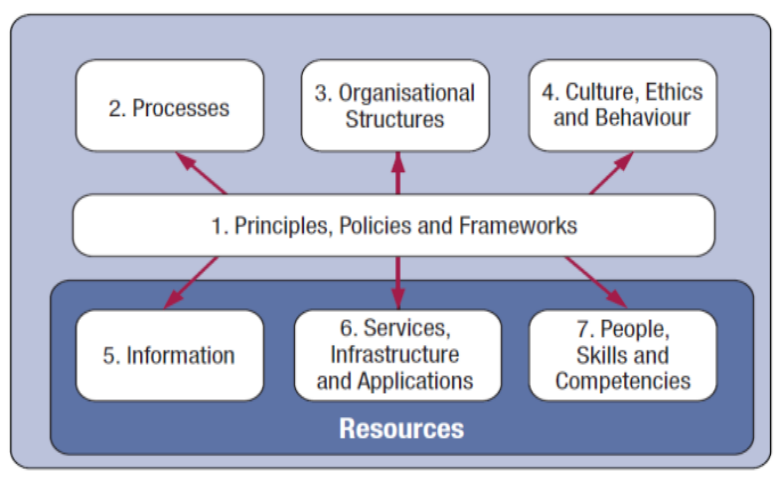

Gambar.2 Tujuh Kategori Pemicu dalam COBIT 5
Prinsip 5 : Separating governance from management (pemisahan tata kelola dan manajemen)

COBIT membuat perbedaan yang cukup jelas antara tata kelola dan manajemen. Kedua hal tersebut mencakup berbagai kegiatan yang berbeda, memerlukan struktur organisasi yang berbeda, dan melayani untuk tujuan yang berbeda pula. Perhatikan Gambar 3.

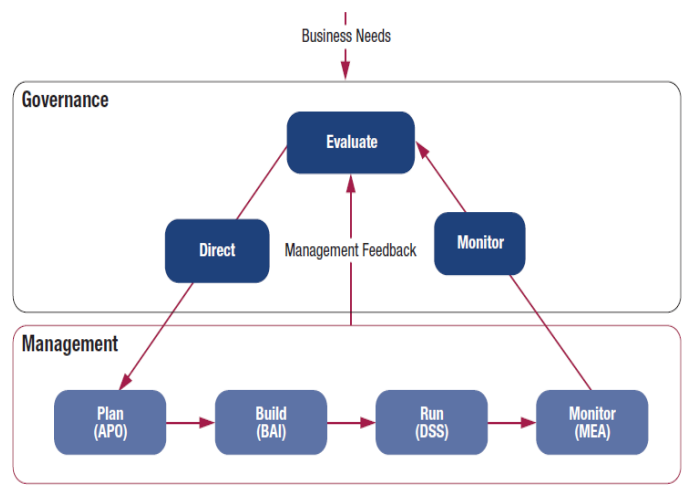

Gambar.3 Area Kunci Tata kelola dan Manajemen dalam COBIT 5

Perbedaan Governance (Tata kelola) dengan

Management (Manajemen) adalah :

1) Governance adalah tata kelola yang memastikan bahwa tujuan perusahaan dapat dicapai dengan melakukan evaluasi terhadap kebutuhan, kondisi, dan pilihan stakeholder, menerapkan arah melalui prioritas dan pengambilan keputusan terhadap arah dan tujuan yang telah disepakati. Pada Kebanyakan perusahaan, tata kelola adalah tanggung jawab dari dewan direksi dibawah kepemimpinan ketua.

2) Management (Manajemen) berfungsi sebagai perencana, membangun, menjalankan dan memonitor aktifitas-aktifitas yang sejalan dengan arah yang ditetapkan oleh badan tata kelola untuk mencapai tujuan perusahaan. Pada kebanyakan perusahaan, manajemen menjadi tanggung jawab eksekutif manajemen dibawah pimpinan CEO.

\subsection{Model Referensi Proses dalam COBIT 5}

Dalam COBIT 5 terdapat suatu model referensi proses yang menentukan dan menjelaskan secara detail mengenai proses tata kelola dan manajemen[6]. Model tersebut mewakili semua proses yang biasa ditemukan dalam perusahaan yang berhubungan dengan aktivitas TI, serta menyediakan model sebagai referensi yang mudah dipahami dalam operasional TI dan oleh manajer bisnis. Lihat Gambar 4. 


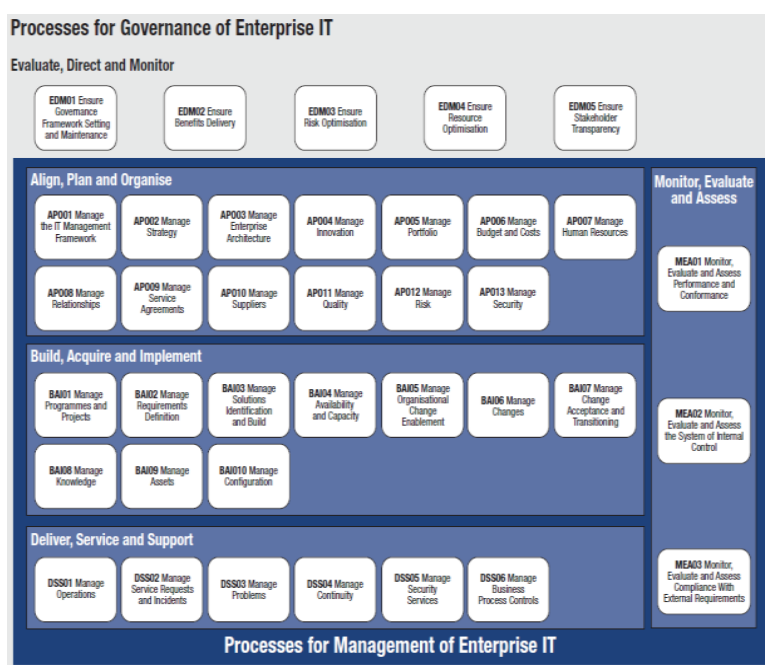

Gambar.4 Model Referensi Proses dalam COBIT 5

Model referensi proses dalam COBIT 5 terdiri atas dua domain proses utama, yaitu :

1. Tata Kelola, memuat lima proses tata kelola, dimana akan ditentukan praktik-praktik dalam setiap proses Evaluate, Direct, dan Monitor (EDM)

2. Manajemen, memuat empat domain, sejajar dengan area tanggungjawab dari Plan, Build, Run, and Monitor (PBRM), dan menyediakan ruang lingkup TI yang menyeluruh dari ujung ke ujung. Domain ini merupakan evolusi dari domain dan struktur proses dalam COBIT 4.1., yaitu:

a. Align, Plan, and Organize (APO) - Penyelarasan, Perencanaan, dan Pengaturan

b. Build, Acquare, and Implement (BAI) - Membangun, Memperoleh, dan Mengimplementasikan

c.Deliver, Service and Support (DSS) Mengirimkan, Layanan, dan Dukungan

d.Monitor, Evaluate, and Assess (MEA) Pengawasan, Evaluasi, dan Penilaian

\subsection{Model Kapabilitas Proses dalam COBIT 5}

Pada COBIT 5 model kapabilitas proses berdasarkan pada ISO/IEC 15504, standar mengenai Software Engineering dan Process Assessment. Model ini sebagai parameter untuk mengetahui performa tiap-tiap proses tata kelola (EDM-based) atau proses manajemen (PBRM based), dan dapat mengidentifikasi area-area yang perlu untuk ditingkatkan performanya.

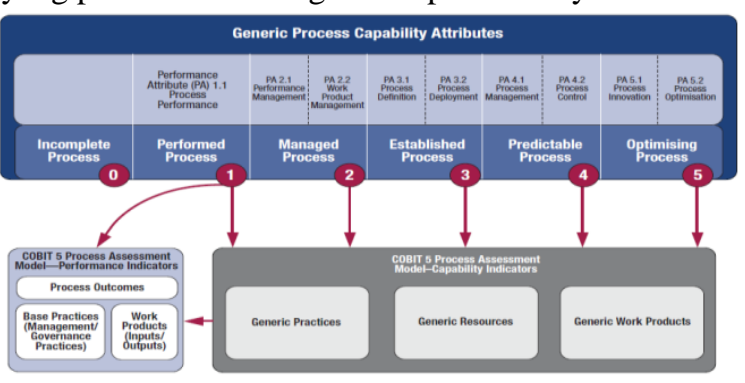

Gambar. 5. Model Kapabilitas Proses dalam COBIT 5
Berdasarkan gambar 5 diketahui bahwa ada enam tingkatan penilaian dalam proses kapabilitas yang dapat dicapai oleh masing-masing proses [6]), perhatikan Tabel 1.

Tabel.1 Enam Tingkatan Penilaian Kapabilitas Proses COBIT 5

\begin{tabular}{|c|c|c|c|}
\hline No & $\begin{array}{l}\text { Tingkat } \\
\text { Kapabilitas }\end{array}$ & Atribut Proses & Keterangan \\
\hline 1 & $\begin{array}{l}0 \text { Incomplete } \\
\text { Process }\end{array}$ & & $\begin{array}{l}\text { Proses tidak } \\
\text { diimplementasikan } \\
\text { atau gagal untuk } \\
\text { mencapai tujuan } \\
\text { dari proses itu. }\end{array}$ \\
\hline 2 & $\begin{array}{l}1 \text { Performed } \\
\text { Process }\end{array}$ & $\begin{array}{l}\text { PA.1.1 } \\
\text { Process } \\
\text { Performance }\end{array}$ & $\begin{array}{l}\text { Implementasi dari } \\
\text { proses sesuai } \\
\text { dengan yang } \\
\text { ditetapkan. }\end{array}$ \\
\hline 3 & $\begin{array}{l}2 \text { Managed } \\
\text { Process }\end{array}$ & $\begin{array}{l}\text { PA. } 2.1 \\
\text { Performance } \\
\text { Management } \\
\text { PA. } 2.2 \\
\text { Work product } \\
\text { management }\end{array}$ & $\begin{array}{l}\text { Proses telah } \\
\text { diimplementasikan } \\
\text { dengan pengelolaan } \\
\text { tertentu } \\
\text { (direncanakan, } \\
\text { dimonitor, } \\
\text { disesuaikan) dan } \\
\text { hasilnya dapat } \\
\text { ditetapkan, } \\
\text { dikendalikan, dan } \\
\text { dipelihara secara } \\
\text { tepat. }\end{array}$ \\
\hline 4 & $\begin{array}{l}3 \text { Established } \\
\text { Process }\end{array}$ & $\begin{array}{l}\text { PA } 3.1 \\
\text { Process } \\
\text { Definition } \\
\text { PA.3. } 2 \\
\text { Process } \\
\text { Deployment }\end{array}$ & $\begin{array}{l}\text { Proses yang telah } \\
\text { diimplementasikan } \\
\text { menggunakan } \\
\text { proses yang } \\
\text { ditetapkan sehingga } \\
\text { mampu mencapai } \\
\text { hasil yang } \\
\text { diinginkan dari } \\
\text { proses itu. }\end{array}$ \\
\hline 5 & $\begin{array}{l}4 \text { Predictabel } \\
\text { Process }\end{array}$ & $\begin{array}{l}\text { PA } 4.1 \\
\text { Process } \\
\text { Measurement } \\
\text { PA. } 4.2 \\
\text { Process Control }\end{array}$ & $\begin{array}{l}\text { Proses yang telah } \\
\text { dijalankan dengan } \\
\text { batasan tertentu } \\
\text { untuk mencapai } \\
\text { hasil yang } \\
\text { dinginkan dari } \\
\text { proses itu. }\end{array}$ \\
\hline 6 & $\begin{array}{l}\text { 5Optimising } \\
\text { Process }\end{array}$ & $\begin{array}{l}\text { PA } 5.1 \\
\text { Proces } \\
\text { Innovation } \\
\text { PA.5.2 } \\
\text { Process } \\
\text { Optimization }\end{array}$ & $\begin{array}{l}\text { Proses yang } \\
\text { implementasinya } \\
\text { mulai ditingkatkan } \\
\text { sehingga sesuai } \\
\text { dengan kondisi saat } \\
\text { ini dan tujuan bisnis } \\
\text { di masa yang akan } \\
\text { datang }\end{array}$ \\
\hline
\end{tabular}

Tujuan penelitian ini mengetahui tingkat kapabilitas pelaksanaan sistem informasi akademik saat ini,dan usulan rekomendasi perbaikan sistem informasi akademik Politeknik Kesehatan Kemenkes Padang berdasarkan proses TI APO07 (mengelola sumber daya manusia)pada framework COBIT 5.

Hasil persentase nilai kapabilitas proses nanti akan digunakan untuk menentukan rating dari Base Practices yang dimiliki proses. Dalam menilai level kapabilitas sebuah proses atribut diberi tingkatan pencapaian (rating) yang dibagi dalam 4 tingkatan yaitu Fully achieved, Largely achieved, Partilly

Jurnal RESTI (Rekayasa Sistem dan Teknologi Informasi) Vol.1 No. 2 (2017) 146 - 152 
Achieved dan Not Achieved. Selengkapnya bisa kita Timur Dengan Model Cobit Framework, hasil dari lihat pada Tabel 2 tentang skala rating atribut proses[6]. penelitian ini adalah sebuah usulan rekomendasi

Tabel 2: Skala Rating Atribut Proses

\begin{tabular}{lcl}
\hline Rating & Simbol & Skala Ordinal \\
\hline Not Achieved & $\mathrm{N}$ & $0-15 \%$ \\
PartiallyAchieved & $\mathrm{P}$ & $>15 \%-50 \%$ \\
Largely achieved & $\mathrm{L}$ & $>50 \%-85 \%$ \\
Fully Achieved & $\mathrm{F}$ & $>85 \%-100 \%$ \\
\hline
\end{tabular}

Penentuan level dari masing-masing proses dilakukan dengan melihat rating dari masing-masing atribut. Suatu level tertentu tercapai jika rating semua atribut pada level tersebut minimal Largely Achieve $(L)$ dan untuk mencapai level berikutnya maka semua atribut pada level tersebut harus mencapai rating Fully Achieve $(F)$. Selengkapnya mengenai aturan penentuan level ini ditunjukkan oleh Tabel 3.

Tabel 3 :Penentuan Penilaian Level Kapabilitas

\begin{tabular}{|c|c|c|}
\hline Level & Atribut Proses & Rating \\
\hline Level 1 & Process Performance & Lor $F$ \\
\hline \multirow[t]{3}{*}{ Level 2} & Process Performance & $F$ \\
\hline & Performance Management & $L$ or $F$ \\
\hline & Work Product Management & $L$ or $F$ \\
\hline \multirow[t]{5}{*}{ Level 3} & Process Performance & $F$ \\
\hline & Performance Management & $F$ \\
\hline & Work Product Management & $F$ \\
\hline & Process Definition & Lor FL or \\
\hline & Process Deployment & $F$ \\
\hline \multirow[t]{7}{*}{ Level 4} & Process Performance & $F$ \\
\hline & Performance Management & $F$ \\
\hline & Work Product Management & $F$ \\
\hline & Process Definition & $F$ \\
\hline & Process Deployment & $F$ \\
\hline & Process Measurement & Lor $F$ \\
\hline & Process Control & Lor $F$ \\
\hline \multirow[t]{9}{*}{ Level 5} & Process Performance & $F$ \\
\hline & Performance Management & $F$ \\
\hline & Work Product Management & $F$ \\
\hline & Process Definition & $F$ \\
\hline & Process Deployment & $F$ \\
\hline & Process Measurement & $F$ \\
\hline & Process Control & $F$ \\
\hline & process Innovation & Lor $F$ \\
\hline & process Optimization & Lor $F$ \\
\hline
\end{tabular}

Penelitian menggunakan kerangka kerja COBIT telah banyak dilakukan oleh peneliti diantaranya Syukri (2013), yang menggunakan kerangka kerja COBIT 4.1 yang menghasilkan sebuah usulan rekomendasi upaya perbaikan kepada pihak manajemen Universitas Negeri Padang untuk proses TI DS4, DS8, dan DS11[7].

Penelitian Riza Nugraha (2012) dengan judul penelitian tentang pengukuran tingkat kematangan teknologi informasi dengan menggunakan kerangka kerja Cobit 4.1 Studi kasus pada PT.XYZ dan Wowon Priyatna (2012) dengan judul penelitian Pengaruh Kematangan, Kinerja Dan Pemanfaatan Teknologi Informasi Terhadap Implementasi SI Di SMK Negeri Jakarta perbaikan untuk manajemen teknologi informasi yang lebih baik lagi[8].

Penelitian Abdul Hakim, Hoga Saragih dan Agus Suharto (2014) dengan Judul Evaluasi Tata Kelola Teknologi Informasi dengan Framework COBIT 5 di Kementerian ESDM (Studi Kasus pada Pusat Data dan Teknologi Informasi ESDM). Penelitian ini bertujuan untuk mengetahui sejauh mana pengelolaan dan pemanfaatan TI dalam meningkatkan pelayanan TI di KESDAM serta memberikan rekomendasi usulan kebijakan pengelolaan TI yang efektif dan efisien dengan menggunakan model COBIT 5[9].

Penelitian Devi Fitrianah dan Yudho Giri Sucahyo (2013) Tentang Audit Sistem Informasi/Teknologi Informasi Dengan Kerangka Kerja Cobit Untuk Evaluasi Manajemen Teknologi Informasi di Universitas XYZ. Hasil penelitian adalah berupa rekomendasi jangka pendek yaitu melakukan kegiatan yang bersifat segera dilakukan agar proses TI dapat berjalan dengan baik, jangka menengah yaitu mengklasifikasikan rencana strategis TI dan jangka panjang dengan membuat kebijakan universitas setingkat kebijakan organisasi[10].

Berdasarkan hasil penelitian terdahulu maka temuan dalam penelitian ini akan dijadikan sebagai dasar rekomendasi perbaikan dalam pengelolaan sistem informasi akademik Politeknik Kesehatan Kemenkes Padang. Rekomendasi perbaikan ini dibuat berdasarkan proses TI terpilih pada COBIT 5 yaitu APO07.

\section{Metodologi Penelitian}

Penelitian ini merupakan penelitian evaluasi untuk menilai kondisi sistem informasi akademik Politeknik Kesehatan Kemenkes Padang saat ini dengan menggunakan alat ukur kapabilitas proses model COBIT 5. Dalam penelitian ini menggunakan tipe penelitian deskriptif kualitatif. Adapun sifat dari penelitian ini adalah deskriptif, metode deskriptif dapat diartikan sebagai prosedur pemecahan masalah yang diselidiki dengan menggambarkan/ melukiskan keadaan subyek/obyek penelitian (seseorang, lembaga, masyarakat dan lain-lain).

Pengumpulan data dilakukan dengan melaksanakan observasi awal, pengumpulan data profil organisasi terutama tujuan organisasi. Kemudiandilanjutkan dengantinjauan pustaka dilaksanakan untuk mencari metode yang tepat untuk penyelesaian permasalahan yang terjadi melalui buku-buku, internet, yang berhubungan dengan objek yang akan diteliti. Pemilihan proses yang menjadi fokus evaluasi dilakukan dengan pemetaan tujuan organisasi berdasarkan COBIT 5 dengan memperhatikan permasalahan yang ditemukan untuk selanjutnya 
dijadikan sebagai acuan dalam evaluasi sistem informasi akademik.

Tahap selanjutnya adalah pengisian kuisioner oleh subjek penelitian dimana proses untuk memperoleh subjek penelitian adalah langsung ke pengelola sistem informasi akademik Poltekkes kemenkes Padang.

Kuisioner yang digunakan dalam penelitian ini berdasarkan panduan dari COBIT 5 sesuai proses yang terpilih. Kuisioner tersebut digunakan untuk menghasilkan data tentang tingkat kapabilitas proses APO07 (pengelolaan SDM TI).

Hasil pengolahan data kuisioner akan dianalisis menggunakan metode persentase skala Guttman. Menurut Sugiyono (2008:139) Skala pengukuran dengan tipe ini, akan di dapat jawaban yang tegas, yaitu ya atau tidak, benar atau salah, pernah atau tidak, positif atau negative [11], lihat rumus (1)

$$
\% \text { Nilai Kapabilitas Proses }=\frac{\sum \text { jawaban "ya" }}{\sum \text { pernyataan }} \times 100 \% \text {.. (1) }
$$

Hasil persentase nilai kapabilitas proses nanti akan digunakan untuk menentukan rating dari Base Practices yang dimiliki proses. Menurut ITGI dalam buku Process Assesment Model (PAM) dalam menilai level kapabilitas sebuah proses atribut diberi tingkatan pencapaian (rating) yang dibagi dalam 4 tingkatan yaitu Fully achieved (>85\%-100\%), Largely achieved (>50\%-85\%), Partilly Achieved (>15\%-50\%) dan Not Achieved (0\%-15\%).

Jumlah kuesioner diberikan tergantung berapa banyak jumlah proses COBIT 5 yang diteliti dengan masingmasing pertanyaan mempunyai lima pilihan ganda Pac dimana setiap jawaban merupakan perwakilan dari masing-masing tingkat level kapabilitas.

Tahapan berikutnya setelah diketahui kondisi tingkat kapabilitas proses Sistem informasi Akademik Poltekkes Kemenkes Padang saat ini maupun target yang diharapkan, maka langkah selanjutnya adalah analisis kesenjangan (gap). Analisis kesenjangan dilakukan untuk mengidentifikasi rekomendasi perbaikan dan peningkatan level kapabilitas proses pada Sistem informasi Akademik Politeknik Kesehatan Kemenkes Padang.

\section{Hasil dan Pembahasan}

Berdasarkan hasil pengolahan data pada kuesioner penelitian diperoleh hasil penelitian berupa rekapitulasi tingkat kapabilitas dari masing-masing proses seperti pada Tabel 4.

Berdasarkan hasil pengolahan data kuisioner tingkat kapabilitas pada APO07 dapat diketahui bahwa proses APO07 belum mencapai level satu atau dikategorikan pada level 0 . Hal ini disebabkan atribut PA 1.1 tidak mencapai kategori minimal $\boldsymbol{L}$ (largely achieved) karena untuk bisa mencapai level 1 maka atribut PA 1.1 minimal harus kategori $\mathbf{L}$.

Tabel 4 :Rekapitulasi tingkat kapabilitas proses APO07

\begin{tabular}{|c|c|c|}
\hline \multirow{2}{*}{ Atribut } & \multicolumn{2}{|c|}{$\begin{array}{c}\text { Proses } \\
\text { APO07 }\end{array}$} \\
\hline & $\begin{array}{c}\text { Skala } \\
\text { Ordinal }\end{array}$ & Kategori \\
\hline $\begin{array}{l}\text { Level } 1 \text { (PA1.1): Process } \\
\text { Performance (kinerja proses) }\end{array}$ & $49,67 \%$ & $\mathrm{P}$ \\
\hline $\begin{array}{l}\text { Level } 2 \text { (PA2.1) : Performance } \\
\text { Management (manajemen kinerja) } \\
\text { Level } 2 \text { (PA2.2) Work Product }\end{array}$ & $43,75 \%$ & $\mathrm{P}$ \\
\hline $\begin{array}{l}\text { Management (manajemen hasil } \\
\text { kerja) }\end{array}$ & $33,33 \%$ & $\mathrm{P}$ \\
\hline $\begin{array}{l}\text { Level } 3(P A 3.1) \text { : Process Definition } \\
\text { (pendefenisian proses) }\end{array}$ & $36,36 \%$ & $\mathrm{P}$ \\
\hline $\begin{array}{l}\text { Level } 3 \text { (PA3.2) Process } \\
\text { Deployment (penyebaran proses) }\end{array}$ & $38,46 \%$ & $\mathrm{P}$ \\
\hline $\begin{array}{l}\text { Level } 4 \text { (PA4.1) Process } \\
\text { Measurement (pengukuran proses) }\end{array}$ & $30,77 \%$ & $\mathrm{P}$ \\
\hline $\begin{array}{l}\text { Level } 4 \text { (PA4.2) Process Control } \\
\text { (kontrol proses) }\end{array}$ & $36,36 \%$ & $\mathrm{P}$ \\
\hline $\begin{array}{l}\text { Level } 5 \text { (PA5.1) Process Innovation } \\
\text { (inovasi proses) }\end{array}$ & $20,00 \%$ & $\mathrm{P}$ \\
\hline $\begin{array}{l}\text { Level } 5 \text { (PA5.2) Process } \\
\text { Optimisation (optimis proses) }\end{array}$ & $33,33 \%$ & $\mathrm{P}$ \\
\hline
\end{tabular}

Keterangan :

$\mathrm{L}=$ Largelly Achieved (Sebagian besar tercapai), $\mathrm{P}=$ Partially Achieved (sebagian tercapai), $\mathrm{N}=$ Not Achieved (Tidak Tercapai)

Penentuan tingkat kapabilitas yang diharapkan diperoleh hasil bahwa tingkat kapabilitas untuk semua proses baik APO07 (pengelolaan SDM TI ) yang diharapkan adalah level 3 .

Berdasarkan hasil analisa level kapabilitas saat ini (asis) dan level kapabilitas yang diharapkan(to-be)pada sistem informasi akademik Poltekkes Kemenkes Padang Penentuan level dari masing-masing proses mempunyai persyaratan yang telah ditentukan oleh COBIT 5. Suatu Level tertentu tercapai jika kategori semua atribut pada level tersebut minimal Largely Achieved $(\boldsymbol{L})$ sedangkan untuk mencapai level berikutnya maka semua atribut pada level tersebut harus mencapai rating Fully Achieved(F). Untuk lebih jelasnya dapat kita lihat pada Gambar 6.

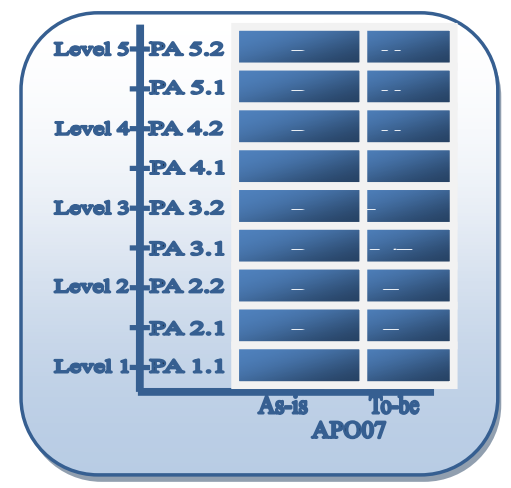

Gambar 6: Grafik Level kapabilitas saat ini dan level kapabilitas Yang diharapkan 
Berdasarkan Gambar 6 dapat di ambil suatu kesimpulan bahwa untuk mencapai level 3 yang diharapkan pada sistem informasi akademik Poltekkes Kemenkes Padang untuk proses manage human resources (APO07)pada atribut processperformance (PA 1.1) pada level 1 , atributperformance management (PA 2.1)danatributwork product management (PA 2.2) pada level 2saat iniberadapada kategori $\mathbf{P}$ atau Partially achieved sedangkan masing-masing atribut tersebut ditargetkan mencapai kategori $\mathbf{F}$ atau fully achieved. Sementara atribut process defeniton( $P A$ 3.1) dan process deployment $(P A$ 3.2) pada level 3ditargetkan mencapai kategori $\mathbf{L}$ atau Largely achieved atau Fully Achieved(F) sedangkan kondisi saat ini masih bernilai Partialy achieved.

Berdasarkan hasil penelitian diatas maka perlu dibuat suatu usulan rekomendasi perbaikan untuk proses TI terpilih pada COBIT 5.

\section{Kesimpulan}

Berdasarkan hasil evaluasi terhadap sistem informasi akademik Politeknik Kesehatan Kemenkes Padang dapat diberikan beberapa kesimpulan.

\subsection{Simpulan}

1. Hasil penilaian tingkat kapabilitas proses APO07 tentang pengelolaan sumber daya manusia TI dalam mengelola sumber daya manusia TI masih rendah.

2. Hasil penilaian tingkat kapabilitas proses APO07belum mampu mencapai level 1, hanya berada pada posisi Partialy Achieved.

\subsection{Saran}

Saran yang dapat diberikan untuk mewujudkan rekomendasi perbaikan pada sistem informasi akademik Politeknik Kesehatan Kemenkes Padang adalah sebagai berikut : a. Mengelola SDM TI (APO07)

Dalam mengelola SDM TI (APO07) Perlu dilakukan Workshop dan Pelatihan terkait pengembangan keahlian SDM TI.

b. Perlu dilakukan evaluasi dan penambahan staf SDM TI agar tidak ketergantungan pada satu individu,

c. Perlu dilakukan perencanaan untuk pengembangan kompetensi dan karir SDM TI,

d. Melaksanakan semuapraktek umum proses APO07 berdasarkan COBIT 5.

\section{Daftar Rujukan}

[1] Ron Weber. 1999. Information System Control and Audit. Prentice-Hall, Inc: New Jersey

[2] R, Robert; Moeller, 2008. Sarbanes-Oxley Internal Control:Effective Auditing With AS5, COBIT And ITIL. John Wiley, USA.

[3] Jogiyanto, HM. 2011 Sistem Tatakelola Teknologi Informasi.Edisi ke-3, Penerbit Andi

[4] ISACA, 2011. COBIT Mapping: Overview of International IT Guidance, 3rd Edition.

[5] Information Technology Governance Institute. (2012). Cobit 5 : Implementation. United States America

[6] Information Technology Governance Institute.(2012).Cobit 5 : Process Assessment Model (PAM): Using COBIT® 5. United States America

[7] Syukhri., 2012. Evaluasi Tingkat Kematangan Proses Delivery and Support pada Implementasi Sistem Informasi Akademik Universitas Negeri Padang Berdasarkan Kerangka Kerja Cobit 4.0 Tahun 2012

[8] Riza Nugraha, Juli 2012. Pengukuran Tingkat Kematangan Teknologi Informasi Dengan Menggunakan Kerangka Kerja COBIT 4.1 Studi Kasus pada PT XYZ. Tesis Pogram Studi Magister Akuntansi. Jakarta.

[9] Abdul Hakim, Hoga Saragih dan Agus Suharto. 2014. Evaluasi Tata Kelola Teknologi Informasidengan Framework COBIT 5 di Kementerian ESDM (Studi Kasus pada Pusat Data dan Teknologi Informasi ESDM). Journal of Information Systems, Volume 10, Issue 2, October 2014

[10] Devi Fitrianah dan Yudho Giri Sucahyo.2013. Audit Sistem Informasi/Teknologi Informasi Dengan Kerangka Kerja Cobit Untuk Evaluasi Manajemen Teknologi Informasi di Universitas XYZ. Jurnal Sistem Informasi MTI-UI, Volume 4, Nomor 1, ISBN 1412-8896.

[11] Sugiyono,2008.Metode Penelitian Kunatitatif Kualitatif dan $R \& D$. Bandung Alfabeta. 